Lima, I.B de; d'Hauteserre, A.M. Ecotourism, social and human capitals, and identity valorization: the communities of Tapajós (PA), Brazil. Revista Brasileira de Ecoturismo,

\title{
Ecotourism, social and human capitals, and identity valorization: the communities of Tapajós (PA), Brazil
}

\section{Ismar Borges de Lima, Anne-Marie d'Hauteserre}

\begin{abstract}
This article deals with the role of community-based ecotourism for strengthening human and social capitals as well as for enhancing culture and forest livelihood of riverbank dwellers in the Tapajós region, in central Amazonia. The research was done based on the premise that ecotourism can be a potential avenue for putting in evidence local culture, identity and singular lifestyles as while it can contribute to strengthen the local networks which can result in collective material and immaterial advantages. The analysis examines the hypothesis that outsiders (the tourists) once they travel to and stay with local communities, they become the primary agents who are in a position to perceive the main aspects of values, beliefs and routines as particularities of an Amazonian livelihood. Even though the visitors usually stay a few days in a certain community, they end up paying enough attention to what the locals tell and do. This way, the tourists involuntarily put the locals at the centre of their visit, to the extent the locals start realizing how important their forest lifestyle is. This argument certainly does not aim at validating the "spetacularisation" of forest people, of their environment and of their culture. Instead, the authors are rather interested in the processes through which outsiders can direct or indirectly - as ecotourism participants - contribute to improve the quality of life and to raise self-esteem of riverbank dwellers. Some Amazonian peoples (of remote areas) usually have a feeling of periphery and of marginalization, because they do not take part in the 'developed metropolitan world'. The self-esteem factor gets relevance in an academic debate, because the Amazonian peoples hold a feeling of being periphery and marginal in reason of not being part of a 'developed metropolitan world'; and this may cause adverse effects on their attitude and expectations. The investigation has a qualitative approach in order to produce descriptive data. Open and semi-structured interviews and participant observation were the main methods used for getting information from the riverbank dwellers.
\end{abstract}

KEYWORDS: Ecotourism; Social and Human Capitals; Forest Livelihood, Culture and Identity Enhancement. 


\section{O Papel do Ecoturismo na Valorização Identitária e no Fortalecimento do Capital Social e Humano nas Comunidades do Tapajós (PA)}

\section{RESUMO}

Este artigo busca investigar o papel do ecoturismo comunitário para o fortalecimento do capital social e humano bem como para a valorização da cultura e da vida dos ribeirinhos na FLONA e na RESEX, na região de Tapajós, na Amazônia central. A pesquisa foi realizada com base na premissa de que o ecoturismo pode ser potencialmente um dos caminhos para se colocar em evidência a cultura e identidade amazônicas ao mesmo tempo em que pode contribuir para fortalecer as redes locais, trazendo vantagens coletivas materiais e imateriais. Busca-se, assim, averiguar a hipótese de que os visitantes, sendo externos ao ambiente em visitação, e por permanecerem naquele ambiente não-urbano, tornam-se agentes responsáveis por uma mudança de percepção nos ribeirinhos acerca deles próprios, levando-os a compreender o tanto que o estilo de vida amazônico, em áreas de floresta pristina, é importante para o equilíbrio e manutenção daquela sociobiodiversidade. Condena-se, no entanto, uma possível 'espetacularização' dos ribeirinhos e de seu estilo de vida. O objetivo é entender os processos pelos quais agentes externos a uma comunidade podem vir a contribuir diretamente e indiretamente - por meio do ecoturismo - para a melhoria da qualidade de vida dos ribeirinhos e elevar a sua autoestima. O fator autoestima ganha relevância no debate acadêmico, pois muitos povos amazônicos (de áreas remotas) possuem um sentimento de serem periféricos e marginais, pois não compartilham do desenvolvimento propiciado pelas metrópoles, isso pode causar efeitos adversos no ânimo e expectativas deles. A pesquisa possui uma abordagem qualitativa com o objetivo de obter material descritivo para análise. Entrevistas abertas e semiestruturadas bem como observação participante foram os métodos usados para se obter informações dos ribeirinhos de Tapajós.

PALAVRAS-CHAVE: Ecoturismo Comunitário; Capital Social e Humano; Valorização da Cultura e Identidade Locais; Tapajós.

\section{Introduction}

In small communities, with an incipient and less structured economy, an ecotourism project - for example - can become the stimulus for positive turns in the dwellers' life (JONES, 2005). When locals are fully involved in ecotourism activities, with direct engagement in decision making and autonomy for management, a situation experienced since the 90 s by some communities and villages in the Tapajós region such as Jamaraquá, Maguari, and Alter-do-Chão, they realize the need for certain skills (JONES, 2005) to cope with new realities and routines. Despite Alter-do-Chão is cited, the village is popularly known as a sun-river beach mass tourism, where 
'ecotourism' is organized by tour operators and local travel agencies, and practiced in surrounding forest areas in that municipality. Alter-do-Chão has approximately 2,000 inhabitants, it is situated in an Area of Environmental Protection (APA) which is an area for conservation and for sustainable activities as set by Brazilian specific legislation; it is about $35 \mathrm{~m}$ distant from Santarém, and Jamaraquá and Maguari are about $60 \mathrm{~km}$ away from it (Figure 1).

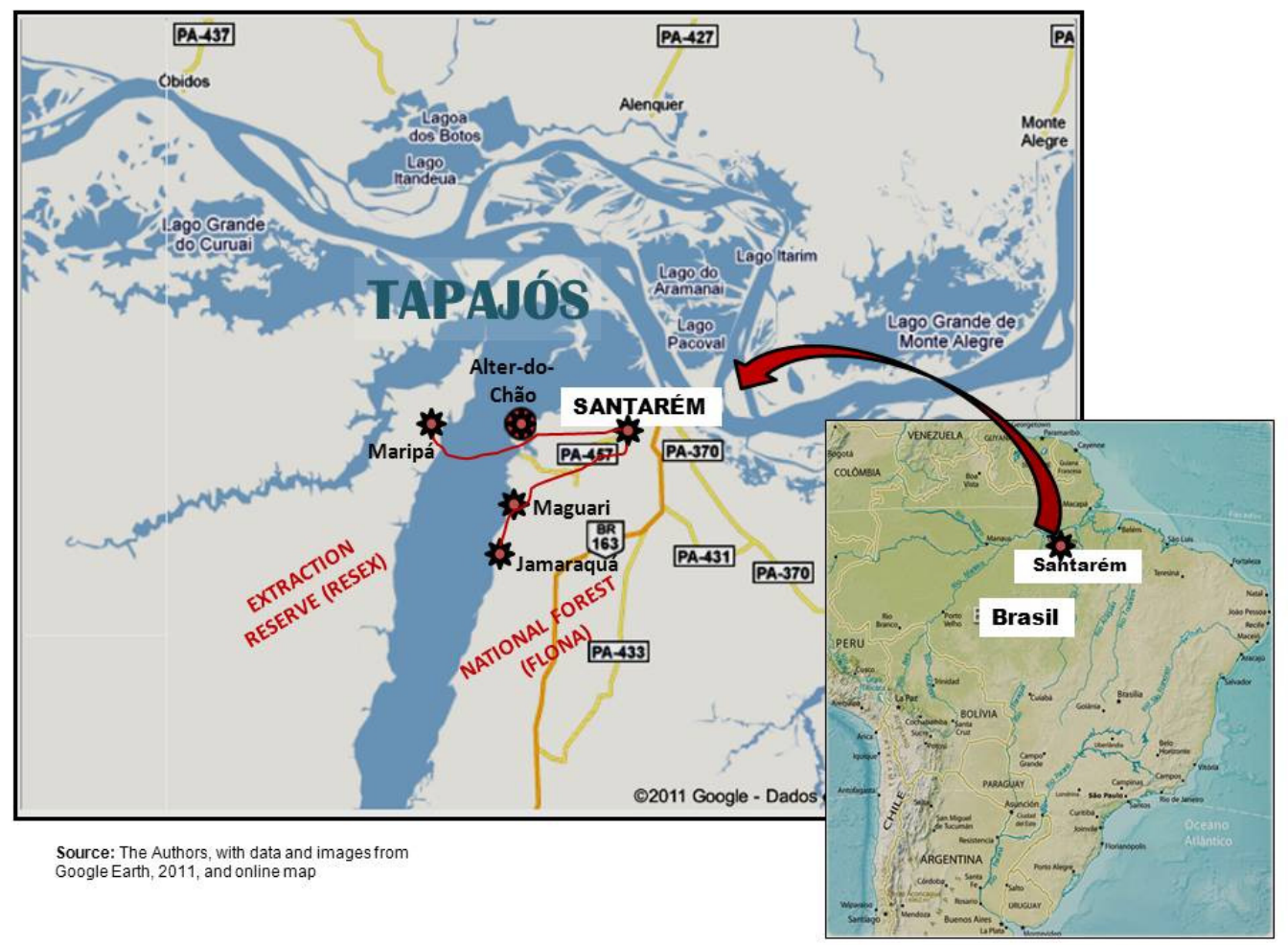

Figure 1: Tapajós region, Central Amazonia: Santarém city, Maripá and Jamaraquá Villages

The terms 'ecological tourism' and 'ecotourism' are used interchangeably, but, in some instances 'nature tourism' is mentioned instead. 'Nature tourism' does not connote ecotourism regarding its complexities and conceptual nuances, but, simply it is 'tourism activities' in natural environments: forests and bushes mostly. In brief, the definition of ecotourism is not exhaustively discussed in this paper because "the general lack of agreement on a universal definition" is well-known (PAGE; DOWLING, 2001, p. 25); it is a worth of note that the literature has many works done on the conceptual approach, featuring 'ecotourism' by insightfully debating it with various interpretations, understandings, and applications, either as an academic discipline or with a tool for regional development, nature protection as well as its social role (NEIMAN, 2009; NEIMAN; MENDONÇA, 2004; RODRIGUES, 2003; ALMEIDA, 2003; RUSCHMANN, 1997). According to Souza and Correa (2000), The official definition of ecotourism in Brazil was provided in 1994 with the publication of the Guidelines for a National Policy of 
Ecotourism, social and human capitals, and identity valorization: the communities of Tapajós (PA), Brazil.

Ecotourism (Diretrizes para uma Política Nacional de Ecoturismo) by Embratur, and has been widely regarded and used (SOUZA; CORREA, 2000; BRASIL, 2008):

It is a segment of the tourism activity which uses, in a sustainable way, the natural and cultural heritage, which promotes conservation and seeks to raise an environmental awareness through nature interpretation, in a way it promotes the well-being to the populations engaged in it (own translation into English).

In this sense, it is better to discuss the key assumptions related to environmental paradigms and human demands; that is, the analysis on 'ecotourism' should include the material and immaterial elements which are part of built and natural spaces as well as the human perception and appropriation over them (ALMEIDA, 2003; ÁVILA, 2009). Gladwin et al. classify the human demands into three paradigms: 'technocentrism', 'sustaincentrism', and 'ecocentrism' (see Table 1). But, the environmental paradigms are interpreted as unresolved dilemmas (ALMEIDA, 2003) which make 'sustainability' a hardreaching goal in conceptual terms. That is why, 'sustainable development' is regarded by many as an oxymoron, and Redclift (2005) says that the concept of 'sustainable development' has come of age, achieving its majority after years of the release of Brundtland report, in 1987, and he inquiries whether it has future or not (p.66).

\begin{tabular}{|c|c|c|c|}
\hline Key Assumptions & Technocentrism & Sustaincentrism & Ecocentrism \\
\hline Human Role & Domination & Stewardship & Plain member \\
\hline Humans and nature & Disassociation & Interdependence & Indisassociation \\
\hline Metaphor of earth & Vast machine & Life support system & Mother/Web of life \\
\hline Resilience of nature & Tough/robust & Varied/fragile & Highly vulnerable \\
\hline Natural capital & Exploit/convert & Conserve/maintain & Enhance/expand \\
\hline Poverty alleviation & Growth trickle & Equal opportunity & Redistribution \\
\hline
\end{tabular}

Table 1: Human Demands and Environmental Paradigms.

Source: Authors, 2008. Adapted from Gladwin, Kennelly and Krause (1994, p.883).

Sustainability has been at the core of ecotourism practices (DOWLING, 2001; WEAVER, 2001a,b, 2005; BJORK, 2007), but on the ground local actors have faced problems in applying the concept (Lima, 2008). 'Sustainable development' is a complex theory, embedded in competing views about how it should be. Ecotourism is proposed to reconcile part of the problematic relation between occupation of natural areas and human impacts (HONEY, 1999). This study maintains that the way in which ecotourism is conceptually envisaged, defined and implemented, must, of necessity, bring all the contradictions sustainability faces to the fore. 
Ecotourism connotes the idea of remote, pristine backwardness and isolated regions, and it has been advertised accordingly. 'Isolation' implies that the communities and villages are geographically situated far from relatively urbanized areas; there is a physical isolation which requires long journeys, but it does not imply total seclusion, because most Amazonian dwellers and indigenous people have been able to keep in contact via wireless and radio communication, TV dishes and collective internet-based telecentres as observed in Jamaraquá. With the current technologies, no human group is entirely cocooned against external influences. As a result, researchers should revise the traditional approaches with respect to 'isolation', 'mediating culture' and 'unchanged traditional cultures'. To be precise, 'isolation' in the text means 'remoteness'.

Although ecotourism has been hyped as the provider of strong sectorial connections, endorsed as an option for restraining leakage of benefits outside a local ecotourism geographical area, and taken as a fosterer of sustainable development (JONES, 2005), it entails some drawbacks. The capitalist-centric orientation in (eco) tourism development can turn into an adverse commodification of rural spaces, culture and lifestyle, since "commodification is an integral part of these processes and social arrangements and therefore underpins the establishment of new rural geographies" (PERKINS, 2006, p. 243). The "commodification of the countryside ideal" (MITCHELL, 1998) can be further explained as a cause-effect of cultural and social displacements (NEPAL, 2006), if the involved communities are not properly assisted and the tour operators have not been regulated and monitored by pertinent authorities and organizations. Maripá, Maguari and Jamaraquá are special cases because they are ruled and abide by an environmental normative framework. In the Resex and Flona there are regulations which establish the limits for human intervention, and the relevance of protected areas for ecotourism practices, and the way backward, that is, ecotourism as of high significance for contributing to nature protection, is a synergetic issue extensively debated in the literature (ROCKTAESCHEL, 2006; KINDER, 2002; NEIMAN, 2002).

In the 1990s, moved by this notion of commodification of inner land areas, the Brazilian government with support of the Inter-American Development Bank (IDB) began an ambitious national ecotourism programme, called Proecotur, to build the needed infrastructure to make ecotourism an attractive sector for business. It would then create sources of income in poor and isolated areas in the Amazonia (LIMA, 2002; LIMA, 2008). Ecotourism is introduced as a symbolic nexus of development, social welfare and conservation (HIGHAM, 2007; BJORK, 2007; LIMA, 2008) with economic promises for the dwellers in the jungle areas of Amazonia. A community ecotourism project does not replace the role of government and institutions for poverty alleviation neither is it a selfgoverning system per se. In fact, ecotourism is mostly reliant on tourists and the money they circulate locally (SCHALLER, 1996).

The problem is the way ecotourism has been discursively clothed (LIMA, 2008; WARD, 1997) which raises high levels of "expectations in communities that are seldom fulfilled" (DRUMM; MOORE, 2005, p. 4), so stakeholders and local actors are disappointed when promises are not fulfilled (WEAVER, 2001a; BJORK, 2007). Residents of Maripá have been sceptical about ecotourism because of underpaid guiding services and local artefacts by most tour operators of nearby cities, Santarém and Alter-do-Chão. Tourism 
seasonality adds to their disenchantment with few occasional tourists appearing for shortstays which do not pay back group and individual time spent on preparations. However, the article sustains Silveira's viewpoint (2005) that ecotourism counts positively for rural development as it bridges the gap of cultural understanding between well-off metropolitan tourists and poor riverbank dwellers in Amazonia. The article does not posit a romantic and naive viewpoint about ecotourism, because as largely discussed in the literature (WEAVER, 2001a,b; PAGE; DOWLING, 2001) even the most well-planned ecotourism activity involves impacts on nature and culture (HALL; BOYD, 2005).

What makes ecotourism a particular case here are the interactive dynamics between 'tourists' and 'locals'. The case studies show that for hosting communities, presenting their folklore, handicrafts, tales and daily life stories to tourists can reduce feelings of inferiority, enhance identity, raise awareness about the importance of the 'self' and revive traditions. Tourism can enhance identities if it is planned with a focus on benefiting an ethnic group (or local community) and with a focus on raising outsiders' awareness about the culture and traditions of a receptive group (LEME, 2009; MELLO, 2003; ALMEIDA, 2003). In addition, the locals must be furnished with the means, tools and skills to deal with tourism activities at a participatory basis in terms of organization and management, including effective interactions between the locals and visitors (LEME, 2009; LINDBERG; HAWKINS, 2001). The Maripá, Maguari and Jamaraquá cases serve to indicate 'whether' and 'how' subjective events and interactions between locals and outsiders in the practices of ecotourism work to improve self-esteem, networks, interactions and associations, human capacity building (EADE, 1998), social cohesion, socio-environmental justice and equity (BECKEN; SCHELLHORN, 2007) within a certain geographical area. Issues of scale (HALL, 2007) are not applied to this investigation because the case studies are managed as self-contained units for data collection and analysis, thus not being crosscut with macro government initiatives for development and social inclusion. Costa et. al. (2009) underline the importance of involving the communities and other stakeholders in ecotourism implementation, adding efforts towards the protection of natural heritage, particularly with respect to the creation and management of trails.

Ecotourism development is complex (BJORK, 2007; HALL, 2007) and the current case studies do not serve as a standardised model to explain similar occurrences in other regions (HIGHAM, 2007). Each ecotourism project has its particularities and uniqueness, and what is reality and truth in one place, may not be applicable to other areas (GOSSLING, 2007; LIMA, 2008). The efficacy of ecotourism for conservation, development and bottom-up participatory management depends on the integration of many elements: norms, regulation, monitoring, funding, fiscal incentives, engagement of individuals and institutions, as well as integrated sectorial actions and well-delivered public policies (LIMA, 2008; WEAVER, 2001a; ÁVILA, 2009). Ecotourism, however, is not a prescription for all economic and social limitations faced by peripheral populations.

For those involved in ecotourism activities, economic benefits can introduce new challenges, with "the erosion of traditional relations of cooperation and reciprocity" (STRONZA; GORDILLO, 2008, p.459). Within the community, internal disputes, misunderstandings about the distribution of ecotourism revenues and taxes, and 
about the division of tasks, can disrupt hierarchies and erode local structures (NEPAL, 2006) mostly because not all stakeholders are always equally well represented. This could result in issues of unbalanced power, "unequal distribution of benefits or neglect of interests of some party" (BJORK, 2007, p. 41), which can make the residents refuse to work collectively and collaboratively. Ecotourism may be therefore perceived as a farfetched initiative for most locals who may conclude that ecotourism cannot bring them relevant benefits. The examples demonstrate that emphasis on an economic orientation (financial capital) over other forms of capital (human, social and natural) may cause the opposite of community integration, well-being, equity, self cultural discovery and coordinated group accomplishments.

Ecotourism implementation is not a smooth and stress free process (WEAVER, 2001a, b; WEARING; NEIL, 1999). Neither does it imply that the whole community will be receptive and participative. Its implementation is in fact a gradual process of assimilation of new routines by the locals, motivation for capacity building, and wishes to get involved. Moreover, locals need time to learn how to deal with outsiders. For meticulously understanding these dynamics, the following questions lead the discussion, i) how does ecotourism contribute to ending the Amazonian communities' feelings that they are historically a marginalized periphery? Issues of core/periphery and marginalization in Amazonia are discussed at different levels and approaches in Pinto (1980), Kitamura (1994), Bartholo Jr. and Bursztyn (1999), and Browder and Godfrey (1997). ii) How does ecotourism contribute to enhance community capitals? The assumption is that ecotourism shapes social practices through interplays among stakeholders affecting positively or negatively any pre-existing human, social and natural capitals. This article seeks to contribute to 'tourism geography' by contextualizing community capitals, (eco)tourism and culture enhancement as a fact in Central Amazonia.

The enhancement of social capital can bring spatial and temporal transformations, heightening local communities' principles of sharing and of collective learning (PONCHIROLLI, 2000) as well as their capacity building (TALBOT; WALKER, 2007). It can enable locals to foresee and approach evolving problematic issues which, if left unattended, could turn into sources of community instability (ALLEN, 2001). By nurturing existing networks and interactive processes, local actors can be better positioned to manage social and economic limits and needs. The richness of an organised human grouping can, among other factors, be measured by this pooling of knowledge and of networks for problem solving (SABATINI, 2008); belonging to networks with informal links to like-minded individuals can significantly strengthen the position of those actors inspired and enabled to cooperate for changes.

Interactive processes from within a group or community in rural areas can propitiate views, behaviour changes and pathways which can become beneficial for integrated regional development (PANELLI, 2006; ALLEN, 2001) as well as for the stakeholders entrusted with the accountability for sustainable management of natural heritage. Kauffman (1959) introduced the concept of community as a field of social interactions, and with high degrees of social capital, "a preliminary forum for increased acquaintanceship" (ALLEN, 2001, p.120). Tools for conflict resolution can facilitate a "livelihood stability" which is essential for development. 
By taking all these conceptual aspects into account, this article examines the constructive role of ecotourism in strengthening the social capital. Tourism, and its variations such as ecotourism, has had a key role for economic growth, alleviation of poverty and environmental conservation (JONES; WOOD, 2007); it is a powerful tool for economic development in lesser developed countries (LDCs) with a demonstrated increase of revenues per year of 154\% between 1990 and 2000 (ROE et al., 2004, p.7). Ecotourism has enabled "turning biodiversity into tourist attractions [which] provides an opportunity to bridge the gap between natural resource conservation and community development" (LAI; NEPAL, 2006, p.119).

\section{Methodological Tools}

A qualitative methodology enables an understanding of the phenomena studied, through attention to detail and use of intimate knowledge about specific situations. It focuses on meanings and on the interests that socially construct the conditions studied. Such methodology does not, however, seek generalizable principles (STEDMAN, 2003, p.824) so it creates challenges for direct comparisons and for repetitive hypothesis testing in other sites. Because of the essence of this investigation, a qualitative methodology was used to capture the social world under investigation as a human creation. Such a methodology means reality is captured through interaction, which was possible because one of the authors is Brazilian, thus, fluent in Portuguese and aware of regional and cultural issues. The article is mostly based on observations and interviews with the members of several communities and 42 local stakeholders involved directly in nature tourism activities, during a three-month field trip to Amazonia in 2005. The last direct contact was a 30-minute interview with Ibama's staff, in November in 2010, regarding tourism advances in Maripá, Maguari and Jamaraquá. Updates were done through periodic consultation with key informants and by browsing the websites of organizations such as the Brazilian for the Environment and Water Resources' (Ibama) electronic newsletters. Ibama is a government environmental agency created in 1989, with financial and administrative autonomy; it is linked to the Ministry for the Environment with the mission to help in the implementation of environmental public policies, managing the concessions of environmental licensing and in charge of monitoring the Brazilian biomes on the whole.

Using a qualitative methodology enabled the collection of data required to provide elements to discuss how the social world of Maripá has been constructed and how likely ecotourism is to impact it. This approach helped to better grasp 'local reality' in ecotourism, and to what levels the local residents are conscious about the inherent tradeoffs the activity may require of them. In order to achieve these aims, the following procedures were applied:

a) Open/in-depth and semi-structured interviews wit key actors (e.g. government staff, tour operators, community leaders) in ecotourism, sustainable tourism development and planning; and government staff dealing with sustainable tourism and partnerships and cooperation;

b) Structured participant observation: to establish contact with the subject and places, watching the study units (members of partnership/network), tour operators with 
ecotourists, tourism operations in the community. The information and knowledge acquired as a participant observer was contrasted with the information provided in the interviews and analysed across the information of texts, a form of triangulation to ensure the robustness of the data (brochures, pamphlet, fliers, reports, etc).

Basically, it is a case study which utilizes research procedures that generate descriptive data. The approach is exploratory combining different methods for data collection (triangulation). The inter-method triangulation helped to get varied information on the same topic to overcome any deficiency of a single-method investigation in terms of validity and reliability. For Lamnek (1995), a case study holds several important characteristics: openness for the researcher (no standardisation that might limit the action of the researcher); communicativity that is, action and communication form the reality and are recorded by the researcher; naturalism implies that study relations are not "artificially constructed models;" interpretativity in which social reality is "interpreted reality" (Carroll, 1996). When combined, they allow much more security and flexibility for data collection.

The case study is considered both a data collection method as well as a research model (SARANTAKOS, 1993) because it can provide many of the empirical facts that help to support arguments as well as validate or falsify theoretical statements. As explained by Yin (1994), a case study is an empirical investigation that explores a modern event in reallife context and requires multiple sources of evidence. The Puxirum ecotourism project was chosen to illustrate the situational hierarchy of stakeholders and their contextual involvement.

Participant observation added substantially to my interviews and analysis. It helped in three distinct ways i) it facilitated my approach and relationship with locals, building and strengthening trust; ii) it provided leads and findings that helped to elaborate more wellfocussed interview questions; iii) information provided by interviewees could be contrasted on the ground. On other occasions, the opportunity for talks, interviews and sharing a place - as a participant observer - allowed me to grasp routines and the social fabric, which otherwise, would have been hard to determine from the outside. The fieldwork involved different levels of participant observation. It included staying in local communities in the Amazon forest, going on tourism excursions, interacting with local guides, as well as participating in seminars, meetings, regional events and conferences.

\section{Social Capital: A Conceptual Approach}

Social capital refers to societal interactions shaped by relationships, institutions and norms which construct and weave meaning in peoples' lives. It implies an attribute of individuals in a social context and the way they transform their participation in networks and in groups into economic gains (SOBEL, 2002; JUDGE, 2003). Social capital consists of horizontal associations (agencies linked to communities linked to individuals) and vertical associations (across sectors and agencies) and networks that underpin actions and decisions in a way that facilitates well-being and production. Social capital for example develops as collective interests prevail over individual ones (PUTNAM, 1995; JONES, 2005). Falk and Kilpatrick (2000) affirm that social capital is the "cement of society's goodwill", building up social cohesion through networks and trust for the group's 
deliberate actions.

What distinguishes human from social capital is the fact that 'social capital' is ingrained in the relations between persons and groups rather than inbuilt in the individuals as such (EDWARDS; FOLEY, 1998). The World Bank also differentiates them by attributing 'nutrition, education and health' as determinants of human capital; and social capital as a concept that addresses networks, trust and forms of contacts (COLEMAN, 1990; COCHRANE, 2005). In fact, human capital constructs individual abilities and knowledge, and social capital assembles networks of individuals that can complement each other, propitiating socio-economic gains at local, regional and national levels (PUTNAM, 1995, 2002). Thus, social capital can be briefly defined as, "societal features that comprise trust, associational activity, and norms of civic behaviour that together facilitate coordination and cooperation for collective benefit" (CLERCQ; DAKHLI, 2003, p.10)

James Coleman, considered a pioneer in the investigation and uses of the concept of social capital, defines it as people's wills to assist each other, being either a group or an organization, in order to implement and manage projects that target collective interests (COLEMAN, 1988, 1990; DIWAN; SIRKER, 1997). Coleman underlines that, just as other forms of capital, social capital secures achievements, in a group, community, or in society, that otherwise would not be possible. Personal growth and networks function as "bonding ties" for social cohesion and become critical for societies to prosper economically and for development to be sustainable. Understanding the dimensions of social capital will enable us to identify converging areas or elements through which networks can positively affect a community. In the literature review, some researchers have established 'dimensional characteristics' of social capital (see Table 2).

\begin{tabular}{|c|c|c|c|}
\hline Woolcock,1998 & $\begin{array}{l}\text { Office of National Statistics } \\
\text { (ONS) .Source: Franke, } 2005 .\end{array}$ & $\begin{array}{l}\text { Liu and Blesser, } \\
2003\end{array}$ & $\begin{array}{l}\text { Narayan and } \\
\text { Cassidy } 2001 .\end{array}$ \\
\hline $\begin{array}{l}\text { i) Integration } \\
\text { ii) Integrity } \\
\text { iii) Synergy } \\
\text { iv) Linkage }\end{array}$ & $\begin{array}{l}\text { i) Participation, social } \\
\text { engagement, commitment } \\
\text { ii) Control, self-efficacy } \\
\text { iii) Perception of community } \\
\text { iv) Social interaction, social } \\
\text { networks, social support } \\
\text { v) Trust, reciprocity, social } \\
\text { cohesion. }\end{array}$ & $\begin{array}{l}\text { i) Informal social } \\
\text { ties } \\
\text { ii) Formal social } \\
\text { ties } \\
\text { iii) Trust } \\
\text { iv) Norms of } \\
\text { collective } \\
\quad \text { action }\end{array}$ & $\begin{array}{l}\text { i) Group } \\
\text { characteristics } \\
\text { ii) Generalized } \\
\text { norms } \\
\text { iii) Togetherness } \\
\text { iv) Everyday } \\
\text { sociability } \\
\text { v) Neighbourhood } \\
\text { connections } \\
\text { vi) Volunteerism } \\
\text { vii) Trust }\end{array}$ \\
\hline
\end{tabular}

Table 2: Dimensional characteristics of social capital as seen by key area researchers. Source: Authors, 2006, based on figures available in the literature 
Lima, I.B de; d'Hauteserre, A.M.

\section{Community Ecotourism Projects}

\section{The Tapajós polygon (Resex and Flona), Brazilian Amazonia}

The chosen cases are located in the Tapajós/Arapiuns polygon, in Pará state. The polygon encompasses Santarém city and Alter-do-Chão village as well as the communities of Jamaraquá, Maguari e Maripá which belong to two distinct Brazilian 'Conservation Units' (UCs) called Resex, Extractive Reserve of Tapajós/Arapiuns with 677,000 hectares, and Flona, National Forest of Tapajós with 545,000 hectares (refer to Table 3 for socioeconomic information). Flona and Resex belong to the National System of Conservation Units (SNUC) which was established on the 18 of July of 2000, law 9985, with respect to legal environmental policies. The SNUC has ten major categories of protected areas which can be created (demarcated) at district, state and national levels. Regarding the SNUC, Brazil has 292 protected areas: 126 of them are fully environmentally protected with rigid regulation restricting human presence; 166 have more flexible rules and norms, allowing human settlements and sustainable use of forest resources.

In the Tapajós region, Santarém is by far the largest urban concentration at the heart of the Amazonian rainforest, with around 170,000 inhabitants. It is $50 \mathrm{kms}$ from the case studies located north and south (around 2 6 hours by small power-driven boat known as voadeira and rabeta). Alter-do-Chão is about one and half hours from Maripá by boat. Tapajós River is the communities' "lifeblood" and the main "highway" which interlinks and serves them. Maripá, Maguari and Jamaraquá have community ecotourism projects supported by the Brazilian Institute for Environment and Renewable Resources (Ibama), local and state governments, civil society such as Saúde Alegria, and by some international donors and partners. Maripá hosts the Puxirum ecotourism project financially supported through a partnership between the Brazilian and Finnish governments.

Maripá, Maguari and Jamaraquá are regulated and monitored by Ibama. The communities can only have low impacting activities such as latex extraction, fruit gathering, subsistence agriculture, subsistence hunting and sustainable management of forest resources. A limited number of dwellers are allowed to live in the Resex and in the Flona. They are usually families who were already living in the region before it got the status of Extractive Reserve. Because the families live in an 'environmental protection area', they are expected by Ibama and the Ministry for the Environment to look after their own environmental assets and forest food sources.

The territory is state land under permanent concession for the families. Most are of mixed European and indigenous ethnicity. The economy is extremely fragile. The families survive by cultivating cassava, fishing, raising domestic animals such chickens, ducks, pigs, processing honey, producing handicrafts, wood kitchen utensils, straw artifacts, manufacturing ecological leather as well as selling flour in Santarém and Alter-do-Chão. The 'better-off' people seem to be the retired ones because they have a monthly salary guaranteed by the government which means they always have cash to purchase goods. During the rainy season most families have less available land for crops; consequently they do not have much for balanced meals, particularly in Maripá because it is settled in a strip segment of forest. Some of the families do risk starving as they struggle daily for their well-being. This is because fish their main source of animal protein - becomes very difficult to catch with the river flowing 10 meters above the original banks. In the Resex, large scale agriculture is absolutely prohibited. 
Ecotourism is one of the commercial activities allowed by lbama in the Resex and Flona. It is statutory that the activity must be coordinated by the native population and is expected to bring economic benefits to the riverbank families by increasing their individual and collective assets and income. Visiting communities in the environmental protection areas requires researchers, tourists and tour operators to apply for an official authorization from Ibama in Santarém. There is a government entry fee of about US $\$ 3.00$ per day. Long term stays for visit, study or research require further assessment and permission because of possible impacts on the traditional lifestyle in the communities. Professional photography and filming incur an additional fee of approximately US\$30. These fees go to a government fund to buy fuel and equipments to monitor officially established conservation areas such as Resex.

Maripá was the community selected out of 68 in the extractive reserve to host an ecotourism pilot project. The project is called Projeto Puxirum de Ecoturismo and has technical and marketing support from Ibama, Mãe Natureza tour operator and from travel agencies in Santarém. The project is mostly financed by the Finnish government. Puxirum, which means volunteerism in a local indigenous dialect, is a comprehensive programme for sustainable development in the Arapiuns-Tapajós region and ecotourism is one of its components. The criteria for selection were its proximity to Alter-do-Chão, its spectacular landscapes and fauna, and its existing trails.

The Maripá community has adopted ecotourism with optimism. The project has created plenty of expectations. They hope the activity can turn into a steady income source. The community devoted time and sweat as its contribution to the Puxirum project. In an atmosphere of keen volunteerism, they worked for months to build up a straw and wooden shelter - called in Portuguese Maloca - for lodging the tourists. The Maloca can host 30 people in the hammock space, has a belvedere and is located in a strategic position. It is on the main access road of the village, and its two storey structure facilitates appreciation of the landscape.

In order to start up ecotourism activities, some locals attended guide training courses managed jointly by the Brazilian Micro and Small Business Support Service (Sebrae), a nonprofit organization, and by the Brazilian government environmental agency (Ibama). The locals got together to set up eight trails that cover 98 kilometres as one of the requirements for the community to become part of the Puxirum. As of April 2005, there were nine trained guides aged 20 to 50 . There are no female guides. Usually the women themselves allege that they do not feel confident to take groups inside the forest. They stress that it is better to have men dealing with any unexpected situation (wild animals or accidents) in the jungle areas. They prefer to get involved in handicraft and souvenir production, and the provision of basic services for the tourists.

The community economically benefits from ecotourism in two ways. There is a US $\$ 4.00$ fee for visiting/entering the community area. The tourists also pay about US\$ 4.50 per night to sleep over in the Maloca. This money is kept in a collective community fund for public benefits. Those families that host tourists also get paid for providing food and accommodation. The guides receive about US\$ 12.00 for conducting the tourists no matter the size of the group (usually 6 10 people). Ibama and the community have plans to adjust the guide fees in order to make them fairer. Tourists can buy souvenirs, handicrafts and home-made sweets, which somewhat improves families' incomes. The community's leader and a guide confirm that ecotourism is a complementary earning that strengthens family budgets by up to $40 \%$. 
Lima, I.B de; d'Hauteserre, A.M.

\begin{tabular}{|c|c|c|c|c|c|}
\hline $\begin{array}{c}\text { Location/ } \\
\text { Pará State, } \\
\text { Brazil }\end{array}$ & Santarém & Alter-do-Chão & $\begin{array}{l}\text { Maguari } \\
\text { (Flona) }\end{array}$ & $\begin{array}{c}\text { Jamaraquá } \\
\text { (Flona) }\end{array}$ & $\begin{array}{l}\text { Maripá } \\
\text { (Resex) }\end{array}$ \\
\hline Population & $\begin{array}{l}\text { - About 170,000 } \\
\text { inhabitants }\end{array}$ & $\begin{array}{l}\text { - About } 3,000 \\
\text { inhabitants } \\
\text { (fixed) } \\
{ }^{*} 40,000 \\
\text { inhabitants } \\
\text { (floating) }\end{array}$ & $\begin{array}{l}\text { - About } 40 \\
\text { families/ } 240 \\
\text { inhabitants }\end{array}$ & $\begin{array}{l}\text { - About } 19 \\
\text { families/110 } \\
\text { inhabitants }\end{array}$ & $\begin{array}{l}-45 \\
\text { families/270 } \\
\text { inhabitants }\end{array}$ \\
\hline Distance & -- & $\begin{array}{l}\text { - About } 35 \mathrm{~km} \\
\text { (paved road) } \\
{ }^{*} 2 \sim 4 \text { hours by } \\
\text { boat from } \\
\text { Santarém }\end{array}$ & $\begin{array}{l}-60 \mathrm{~km} \\
{ }^{*} 3 \sim 5 \text { hours by } \\
\text { boat } \\
\text { * } 4 \text { hours by bus } \\
\text { (unpaved } \\
\text { road) from } \\
\text { Santarém }\end{array}$ & $\begin{array}{l}-70 \mathrm{~km} \\
* 4 \sim 6 \text { hours by boat } \\
* 41 / 2 \text { hours by bus } \\
\text { (unpaved road) } \\
\text { from Santarém }\end{array}$ & $\begin{array}{l}-60 \mathrm{~km} \\
{ }^{*} \text { No road } \\
\text { access } \\
{ }^{\star} 4 \sim 5 \text { hours by } \\
\text { boat from } \\
\text { Santarém } \\
{ }^{*} \text { About } 22 \mathrm{~km} \\
\text { from Alter-do- } \\
\text { Chão ( } 11 \frac{1}{2} \\
\text { hour } \\
\text { by boat). }\end{array}$ \\
\hline Economy & $\begin{array}{l}\text {-River port, local } \\
\text { business, farming } \\
\text { and mineral trade, } \\
\text { river transport, } \\
\text { food processing, } \\
\text { aviary, cereals } \\
\text { storage } \\
\text { and processing, } \\
\text { services, public } \\
\text { and private } \\
\text { sectors, local } \\
\text { manufacturing, } \\
\text { urban tourism. }\end{array}$ & $\begin{array}{l}\text {-Nature mass } \\
\text { tourism, fishing, } \\
\text { aviary, local } \\
\text { transport, } \\
\text { agriculture, hotel } \\
\text { and restaurants } \\
\text { services, public } \\
\text { sector, } \\
\text { handicrafts and } \\
\text { local } \\
\text { manufacturing. }\end{array}$ & $\begin{array}{l}\text {-Subsistence } \\
\text { agriculture, fishing, } \\
\text { aviary, hunting, } \\
\text { latex extraction \& } \\
\text { ecological leather } \\
\text { manufacturing, } \\
\text { woodworking, } \\
\text { natural aromatic } \\
\text { oils, honey, } \\
\text { baskets, fruit } \\
\text { preserves, and } \\
\text { ecotourism. }\end{array}$ & $\begin{array}{l}\text { - Subsistence } \\
\text { agriculture, aviary, } \\
\text { fishing, hunting, latex } \\
\text { extraction \& } \\
\text { ecological leather, } \\
\text { ecotourism. } \\
\text { Woodworking, natural } \\
\text { aromatic oils, honey, } \\
\text { baskets, fruit } \\
\text { preserves, and } \\
\text { ecotourism. }\end{array}$ & $\begin{array}{l}\text {-Subsistence } \\
\text { agriculture, } \\
\text { aviary, fishing, } \\
\text { hunting, } \\
\text { manioc flour } \\
\text { production, } \\
\text { ecotourism. }\end{array}$ \\
\hline $\begin{array}{l}\text { Tourism } \\
\text { activity/ } \\
\text { attractions }\end{array}$ & $\begin{array}{l}\text { Main tourism } \\
\text { gate (river port \& } \\
\text { airport). River boat } \\
\text { cruises. Shopping } \\
\& \text { traditional } \\
\text { cuisine and } \\
\text { handicrafts. It is } \\
\text { Surrounded by } \\
\text { rainforest, lakes, } \\
\text { lagoons, } \\
\text { 'igapós' (flooded } \\
\text { forests) and } \\
\text { 'igarapés' (lagoons } \\
\text { with crystalline } \\
\text { water). }\end{array}$ & $\begin{array}{l}\text { Surrounded by } \\
\text { forests. 'Igapós' } \\
\text { and 'igarapés'. } \\
\text { Alter-do-chão } \\
\text { hosts the most } \\
\text { appreciated river } \\
\text { beach in the } \\
\text { Tapajós. The } \\
\text { green lake is a } \\
\text { tourist hotspot. It } \\
\text { changes from } \\
\text { blue to green } \\
\text { during the day. } \\
\text { Piroca hill. Local } \\
\text { culture and } \\
\text { cookery. Bird } \\
\text { watching. Native } \\
\text { guides. Picturing } \\
\text { wildlife. }\end{array}$ & $\begin{array}{l}\text { Primary and } \\
\text { secondary } \\
\text { rainforest. } \\
\text { Long trails. Bird } \\
\text { watching. Sport } \\
\text { fishing. Local } \\
\text { culture and cookery. } \\
\text { Bathing in the lakes. } \\
\text { lgarapés \& igapós. } \\
\text { Typical fruits. Giant } \\
\text { Samaúma trees. } \\
\text { Bird watching. } \\
\text { Native guides. } \\
\text { Picturing wildlife. }\end{array}$ & $\begin{array}{l}\text { Primary and } \\
\text { secondary rainforest. } \\
\text { Long trails. Bird } \\
\text { watching. Sport } \\
\text { fishing. Local culture } \\
\text { and cookery. Bathing } \\
\text { in the lakes. Igarapés } \\
\text { \& igapós. } \\
\text { Typical fruits. Giant } \\
\text { Samaúma trees. Bird } \\
\text { watching. Native } \\
\text { guides. Picturing } \\
\text { wildlife. }\end{array}$ & $\begin{array}{l}\text { Primary and } \\
\text { secondary } \\
\text { rainforest. } \\
\text { Long trails. } \\
\text { Bird watching. } \\
\text { Sport fishing. } \\
\text { Local culture } \\
\text { and cookery. } \\
\text { Bathing in the } \\
\text { lakes. Igarapés } \\
\& \text { igapós. } \\
\text { Typical fruits. } \\
\text { Bird watching. } \\
\text { Native guides. } \\
\text { Picturing } \\
\text { wildlife. }\end{array}$ \\
\hline
\end{tabular}

Table 3: Socioeconomic Information and figures of Tapajós/Arapiuns. polygon, in Pará state, Brazilian Central Amazonia. Source: The authors, 2008. 
Ecotourism, social and human capitals, and identity valorization: the communities of Tapajós (PA), Brazil.

\section{Puxirum Community-based Ecotourism, Cooperation and Social Capital}

The major partnership for Maripá has been the Puxirum ecotourism project. It has functioned as a catalyst of members' attention and efforts. The importance of Puxirum is evident for harnessing community integration and for generating income. The project is the result of community and institutional efforts to broaden locally their economic and income horizons through ecotourism. There are many direct and indirect partners involved in the Puxirum at local and regional levels. However, interaction is sporadic; it mostly happens in a fragmented way, not involving all dwellers. The intra-community networks seem to be much stronger than the links the villagers have with outsiders. The reason may be that community members share opinions and know each other well in terms of personality, behaviour, way of thinking; they share the same customs, culture and identity, and make decisions jointly over small or major themes on a daily basis.

In Maripá, the intra-community networks become a continuum for reaffirming and reinforcing them as a unit - a sense of belonging - with relations based on intense 'trust' and 'reliability' as one of the natives explains their daily life and interaction, 'we are part of this land for generations; we know each other, the families and our next of kin very closely; we have a way of things and this makes us the whole here one supporting the other, because we need it to overcome daily difficulties'. Conversely, it was observed in Maripá and Maguari that there were levels of anxiety between locals and outsiders when initiating an interactive process; it was mostly manifested in the form of silences (a refusal by the locals to talk and interact), shyness and reclusion.

Although the methodology used is not deeply ethnographic, it is possible to assert that the networks (see Figure 2.0) contribute at different levels to increase human capital within Maripá because they bring a variety of benefits to the community. This accumulation of human capital, in turn, makes the networks more resilient and durable. The assumption is that human capital and social capital are inseparable elements of a family, group, community and society. They complete each other and form the basis for the acquisition of other forms of capital such as financial, political and intellectual. Each network contributes to strengthen an area of knowledge of the community (JONES, 2005). For instance, Projeto Saúde e Alegria is a non-governmental organization with more than 20 years working in the Tapajós-Arapiuns polygon (central Amazonia). It has improved the communities' quality of life by providing knowledge, techniques, and equipment for the communities' activity. In Maripá, Saúde e Alegria's contribution during the field trip was the technical and physical support to install the community radio station with speakers on the street light poles as well as the two windmills for producing clean energy.

Another example of how networks enrich social capital is Maripá's connections with labour and class associations. It has links with the Rubber-tappers' National Council (CNS), the Resex Communities' Association, Amazonian Agro-Extractive Center (CAAM) and CPT Association. This type of networks helps communities like Maripá get informed and updated about issues pertinent to them (Fig. 1). They also favour accumulation of knowledge when community members productively get together for open discussion on social, emotional and subjective issues. This was observed to occur in the 'Young Groups' and 'Church'. Within their group they feel stronger and can overcome limits while they get others' views before making personal decisions. In fact, these associations become forums for debate and decision-making over personal, group, labour and class matters. 
Such networks promote segmented gains directly or indirectly for those linked to them. Networks are the basis for social capital to exist, and social capital functions as a crosssectorial platform through which decisions are made, advancing regional development and people's well-being.

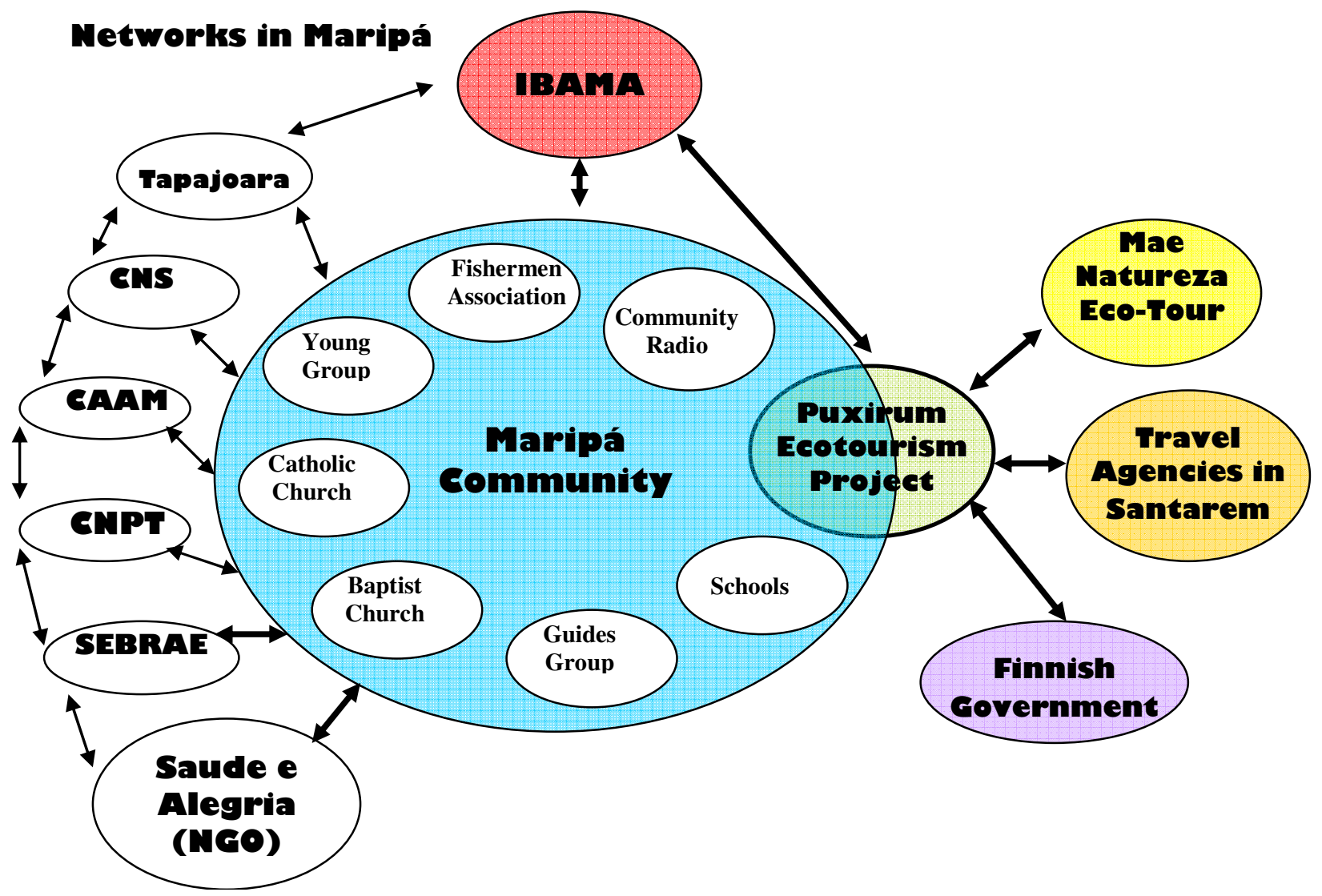

Figure 2: Key networks in Maripá. Source: The authors, 2008.

Deconstructing Maripá's networks has demonstrated how networks help constitute social capital and problem solving and how they expand interpersonal trust, optimism and non-party political participation. The community has a combination of types of social capital because of the internal and external dynamics of its networks. Maripá retains both characteristics of 'bonding and bridging capitals' with vertical and horizontal links; the cognitive and structural social capitals are intertwined in Maripá with on-going cooperation because of continuous reinforcement of trust, values, and norms. Maripá seems to have more continuous networks than short-lived ones; this provides the basis for strong social capital. It seemed, during the course of my stay, that there was much solidarity among the members of Maripá and this fact indicates principled social capital as well. Its networks are predominantly within the delimited area of Resex which sets Maripá as a circumscribed social capital. This aspect confirms that a networked community, supported by civil society, can be a changing place, Eade (1998, p.165), understands that, 
A dynamic network is not just a cosy club. Its participants are active and keen not merely to reinforce their existing knowledge and beliefs, but also be introduced to new ideas...To 'scale-up' or enhance their impact depends on optimising the effectiveness and efficiency for the benefit of the poor...Many people and organisations draw real strength and confidence just from knowing that they are not alone in their struggles.

In May 2010, the researcher obtained updated information about the communitybased ecotourism. The local leaders (refer to the endnote) indicated that ecotourism was progressing, and they informed me as follows:

- They have received about 40 tourists per month;

- Community has full control of the ecotourism project. Tour operators and agencies are not allowed to mediate business between them and the tourists. The community deals directly with the tourists and, consequently, has increased profits.

- Maloca was improved and has sheltered tourists as planned by the group.

- Local production has contributed to family income;

- Tourists' money has circulated in the whole community; locals have improved their economic assets by selling traditional food, handicrafts, offering their house for tourists to experience their routines and life.

- There are four tracks. They are better equipped for supporting tourists' nature appreciation and ecological experiences;

- Maripá has 350 people (60 families) as of May 2010;

- The natives have mobile phones.

\section{Evolving Human and Social Capitals}

Optimism was observed as the main ingredient in the first stage of adoption of ecotourism. In fact, the structural and emotional community changes, when developing ecotourism, follow 11 phases which fit within two broad dimensions: anxiety and euphoria. The phases pervade the whole process of incorporating ecotourism activities into the community structure. Each phase in the development process adds to or subtracts from community capitals, i.e. contributes to enrich or negatively impacts on human, social, and natural capitals.

Within the conceptual framework focused on human and social capitals, each member is considered as an 'indispensable unit' for group cohesion. One's well-being, learning capacity, esteem, confidence and knowledge become pivotal for the social equilibrium of the group. In poor isolated Amazonian communities, these subjective elements such as esteem and confidence can easily be advanced if locals feel they are important to outsiders. Thus, substantial internal changes in a community can occur from positive interventions by outsiders. This was observed in Maripá when outsiders gave importance to what locals were doing, saying, manufacturing, fishing, and believing; it seemed to reflect immensely in their emotional responses. Ecotourism development can raise expectations, pulling the trigger for locals to envisage possible changes in their lives for the better. 
It was observed that, at the implementation phase of ecotourism, locals who were interested but did not hold the required abilities and knowledge, struggled to the fullest to learn the new skills. The effort for improving pushed locals to interact more and more, strengthening their personal and group networks. Activities that link the locals around 'ecotourism development' were seen to reinforce existing personal connections (cognitive) that directly reproduce the community level connections (structural). It gives the impression that 'social capital' becomes a collective asset deriving from many aspects of people's lives and from their associative goings-on (JONES, 2005). Understanding how social ties and their dynamics constitute an additional means or resource for individuals and communities, and the way in which they can be accessed and used productively, is an avenue that could have significant public policy impact (JONES, 2005; SCHEYVENS, 2002).

\section{Conclusion}

The article sought to reveal how 'ecotourism' can become an enhancer of 'social and human capitals', 'local economy' and of 'identity'. As for the social capital, it is assumed that, with the implementation of ecotourism projects and activities, the local social ties and structures and traditions become even more noticeable for both hosts (the local dwellers) and guests (the tourists). Through interactive processes with the tourists, it seems the locals become more mindful of their own culture and of the importance of natural landscapes for tourism (and for themselves). This change of perception may constructively increase a feeling of belonging in some dwellers to the extent this helps them to struggle for the continuity of ecotourism as one strategic economic activity and for nature preservation. Ecological tourism seems to contribute to strengthen the networks of cooperation and trust in four localities in the Tapajós region: Maguari, Jamaraquá, Maripá communities and Alter-do-Chão village.

When cosmopolitan people come and share space and time with the locals, paying attention to their culture, life-style and environment, a new paradigm takes place: Amazonians in isolated areas gain an inner feeling of social ascension and importance enhancing both social and human capitals. When the [eco]tourists come to support the locals in their own environment, to listen to their stories, myths, day-to-day challenges and difficulties, and set the locals at centre stage during the visit, the tourists have a crucial role in helping these communities overcome social exclusion and feelings of inferiority.

In this sense, ecotourism development significantly contributes to enhance the human, social, and natural capitals in Amazonian communities. This process of hosting tourists makes them feel less marginalized - less peripheral - as they acknowledge that local values and culture are integral to an Amazonian identity. However, it is underlined the importance of planned ecological tourism, particularly to those communities in Amazonia, because rather than strengthening and heightening the embryonic human and social capitals, ecotourism can end up eroding them, creating a metaphorical "social trap" (PUTNAM, 2001), besides causing a feeling of frustration and disappointment.

Ecological tourism activities can help to expand income generation by opening up opportunities for services and businesses such as handicraft selling, and ecotourism 
guidance. Disrespectful ecotourists and businesspersons can inadvertently elicit rejection and feelings of disappointment thrusting the locals against outsiders and against ecotourism itself. A community leader confirmed that, "tour operators just come to here to make as much money as they can, cashing out on us - the weakest side - without giving back a real contribution to us...we feel like subjugated in our own land". In Maripá, locals have asked lbama for fee reviews for their services and for more control over the Puxirum ecotourism project to avoid exploitation by false eco-tour operators. The case is not exclusive or new because many community-based ecotourism projects around the globe have faced the dilemmas and stalemates of weaving together conservation issues and economic ones.

Even though some adjustments and regulation should take place in Maripá, ecotourism has played a role as a capitals enhancer in the community. Ecotourism has instigated locals to improve their pre-existing capitals at least in the initial stages and improved capitals promote well-being (ANDERSON et al., 2004; CARPENTER et al., 2004, KOKA; PRESCOTT, 2002). They underline that enhanced social capital can reduce costs of collective actions at the same time it improves the flow of information, goodwill and motives for cooperation; and it can bring more investments accompanied by more effective monitoring and enforcement systems. But it is still not clear whether social capital can instigate or not individuals into more sustainable practices in land management. Since improved social capital results in powerful social cohesion and networks, these links could be explored to successfully promote environmental education.

The Maripá case reveals that coordinators and community leaders should pay extra attention to the stages and issues that present more chances for causing disagreements and a decrease of expectation. In addition, mechanisms, tools and forums should be created for consensus building, environmental awareness and conflict resolution on legitimacy, finances, rights and responsibilities. The Maripá ecotourism project validates the Falk and Harrison (1998) assumption that it is possible to have social capital in the short term as a form of capacity building. Ecotourism projects which stress investment in human and social capitals, and prioritize participatory processes, have a pivotal role for equitable and sustainable achievements in development (PRETTY; FRANK, 2000, PRETTY; WARD, 2001; MULDERA et al., 2005).

When communities hold multifaceted networks of civic engagement - what can be called 'purposeful networks' in ecotourism development - dwellers are more likely to cooperate for collective gains. In Maripá, locals got involved in ecotourism mainly because of the discourses about its positive prospects. The possibility of change, the novelty, the chance for learning and showing abilities, the arrival of groups of tourists and the financial gains pushed them to communicate and cooperate much more. Expectations can be nourished through a growing flux of tourists with increasing capital inputs [progressive income generation]. This fact reveals that social capital really assembles networks of individuals while it augments human capital (individual abilities and knowledge), complementing each other, for socio-economic gains in the community.

For example, what the Maripá Puxirum ecotourism project demonstrates is that the act of 'building expectations and perspectives' becomes the 'glue' for triggering the whole process of reinforcement of the local culture and for promoting inclusions. As observed by Scheyvens (1999, p.247)., "self-esteem of many community members is enhanced [with ecotourism] because of outside recognition of the uniqueness and value of their culture, their natural 
Lima, I.B de; d'Hauteserre, A.M.

resources and their traditional knowledge". Self-esteem becomes the main ingredient to be worked by leaders and project managers who can use it to overcome the most problematic stages in ecotourism implementation, i.e. the 'constraint', 'uncertainty', 'disappointment' and 'stalemate'. If these phases are well-managed, increasing self-esteem and collaborative attitudes will take place, resulting in a positive scenario for poverty reduction and environment maintenance.

Increased self-esteem propitiated by ecotourism activities could be observed in all contacts with the natives in Maripá. In May 2010, the Puxirum's community leaders confirmed that there are ten people directly and enthusiastically involved with ecotourism; they assist the tourists, work as guides and cater for their well-being in the village. According to the local participants, Issac, Maria Isolina, Raimundo, Raimundinho, Manduca, and Beto, the greatest thing is that they have complete ownership of the enterprise; the community makes decisions over every aspect of ecotourism development. The tourism agencies and operators are not "mediators" in the business as happened in the past

Ecotourism can contribute to reinforce Amazonian identity and culture while reducing physical and historical (socio-economic) distances between developed urban centers and Amazonian people. Because of its principles and foundations - for many - ecotourism is an excuse for safeguarding nature. Without pristine green areas, ecotourism loses its main appeal. Those isolated Amazonian communities attracted attention because they still possessed their native environment and cultural idiosyncrasies.

\section{References}

ALLEN, J.C. Community conflict resolution: The development of social capital within an interactional field. The Journal of Socioeconomics, vol.30, n.2, p.119-120, 2001.

ALMEIDA, M. G. (Org.) Paradigmas do Turismo. Editora Alternativa: Goiânia, 2003.

ANDERSON, C. L., LOCKER, L.; NUGENT, R. Microcredit, social capital, and common pool resources. World Development, 30, p. 95-105, 2004.

ÁVILA, M. A. Política e Planejamento em Cultura e Turismo: Reflexões, Conceitos e Sustentabilidade. Editus, Editora da UESC, Ilhéus, BA, 2009, p. 1-15.

BARTHOLO JR., R.S.; BURSZTYN, M. Amazônia sustentável: Estratégia de desenvolvimento, Rondônia 2020. Brasília: Edições Ibama, 1999.

BECKEN, S.; SCHELLHORN, M. Ecotourism, energy use and the global climate widening the local perspective. In: HIGHAM, J. (Ed.), Critical Issues in Ecotourism: paradoxes, problems and pathways for the future. Oxford: Elsevier, 2007, p. 85-101.

BECKER, G. S. Human capital. In: HENDERSON, D. (Ed.). The concise encyclopedia of economics, 2nd ed. Indianapolis: Library of Economics and Liberty, 2002.

BJORK, P. Definition paradoxes: from concept to definition. In: Higham, J. (Org.). Critical issues in Ecotourism Understanding a Complex Tourism Phenomenon. Oxford, UK: Elsevier Butterworth-Heineman, 2007, p. 23-45.

BOXALL, P.; PURCELL, J. Strategy and human resource management. New York: Palgrave Macmillan, 2008. 
Ecotourism, social and human capitals, and identity valorization: the communities of Tapajós (PA), Brazil.

BRASIL. MTur - Ministério do Turismo. Ecoturismo: Conceitos Básicos. Secretaria Nacional de Políticas de Turismo. EMBRATUR, Brasília, 2008, 64p. Available online <http:// institucional.turismo.gov.br/arquivos_open/diretrizes_manuais/cadernos_manuais/ Livro_Ecoturismo.pdf> Acessado em 20 de Abril, 2011.

BROWDER, J.O.; GODFREY, B.J. Rainforest cities: urbanization, development and globalization of the Brazilian Amazon. New York: Columbia University Press, 1997.

BUCKLEY, R. A framework for ecotourism. Annals of Tourism Research, vol.21, n.4, p. 661 $-665,1994$.

BUCKLEY, R. Environmental impacts of ecotourism. Wallingford, UK: CABI, 2004.

CAROLL, J. Escaping the information abattoir: Critical and transformative research in drama education. In: TAYLOR, P. (Org.), Researching Drama and Arts Education: Paradigms and Possibilities. London: Falmer Press, 1996.

CARPENTER, J. P., DANIERE, A. G.; TAKAHASHI, L.M. Cooperation, trust, and social capital in Southeast Asian urban slums. Journal of Economic Behavior \& Organization, vol. 55, p. 533-551, 2004.

CLERCQ, D.; M. DAKHLI. Human capital, social capital, and innovation: a multi-country study. Brussels, Belgium, Vlerick Leuven Gent Management School, p. 1-41, 2003.

COCHRANE, P. Exploring cultural capital and its importance in sustainable development, Ecological Economics, vol. 57, n.2, p. 318-330, 2005.

COLEMAN, J. Social capital in the creation of human capital. American Journal of Sociology, 94, p. 95-120, 1988.

COLEMAN, J. Foundations of social theory. Cambridge: Harvard University Press, 1990.

COSTA, N. M. C. da; NEIMAN, Z. R.;COSTA, V. C. Pelas Trilhas do Ecoturismo. São Paulo: Editora Rima, 2009.

COSTANZA, R. The value of the world's ecosystem services and natural capital. Nature, $p$. 253-260, 1997.

DASGUPTA, P.; SERAGELDIN, I. (Eds.). Social capital: A multifaceted perspective. Washington: The World Bank, 2000.

DIWAN, I.; SIRKER, K. Towards competitive and caring societies in the Middle East and North Africa. Selections from the Mediterranean development forum: Knowledge and skills for development in the information Age - Mediterranean development forum I. Marrakech, Morocco, World Bank Group, 1997.

DOWLING, R.K. Oceania (Australia, New Zealand and the South Pacific). In: WEAVER, D. B. (Ed.), The Encyclopedia of Ecotourism. Wallingford, UK: CABI Publishing, 2001, p.139-154.

DRUMM, A.; MOORE, A. Ecotourism development: A manual for conservation planners and managers: An introduction to ecotourism planning, second edition, vol.2, The Nature Conservancy, Arlington, Virginia, USA, 2005.

EDWARDS, B.; FOLEY, M. W. Civil society and social capital beyond Putnam. American Behavioural Scientist, vol. 42, p. 124-139, 1998. 
Lima, I.B de; d'Hauteserre, A.M.

FALK, I.; HARRISON, L. Community learning and social capital: Just having a little chat. Journal of Vocational Education and Training, vol.50, n.4, p. 609-627, 1998.

FALK, I.; KILPATRICK, S. What is social capital? A study of interaction in a rural community. Sociologia Ruralis, vol. 40, n.1, p. 87-110, 2000.

GOSSLING, S. Ecotourism and Global Environmental Change. In: HIGHAM, J. (Ed.), Critical Issues in Ecotourism. Oxford, UK: Elsevier Butterworth-Heinemann, 2007, p. 70-84.

HALL, C.M. Scaling ecotourism: the role of scale in understanding the impacts of ecotourism. In: HIGHAM, J. (Org.), Critical Issues in Ecotourism: Understanding a complex tourism phenomenon. Amsterdam: Elsevier, 2007, p. 243-255.

HALL, C.M.; BOYD, S. Tourism and nature-based tourism in peripheral areas: Development or disaster. Clevedon: Channelview Publications, 2005.

HAWKEN, P., LOVINS, A.; LOVINS, H. Natural capitalism: creating the next industrial revolution. Boston, Little: Brown and Company, 2000.

HIGHAM, J.E.S. Critical issues in ecotourism: Understanding a complex tourism phenomenon. Oxford: Elsevier Butterworth-Heinemann, 2007.

HONEY, M. Ecotourism and sustainable development: Who owns paradise? Washington. D.C.: Island Press, 1999.

HUANG, F. Social trust, cooperation, and human capital, Singapore Management University, mimeo, p.1-36, 2003.

JONES, S. Community-based ecotourism: The significance of social capital. Annals of Tourism Research, vol. 32, n.2, p. 303-324, 2005.

JONES, T.; WOOD, D. Calculating the tourist expenditure generated by natural and heritage areas: The valuing places toolkit. Conference proceedings, Tourism: Past Achievements, Future Challenges, 11/02/2007. Sydney, Australia: University of Technology, 2007.

JUDGE, R. Social Capital - building a foundation for research and policy development. Policy Research Initiative - Feature Articles, Government of Canada. Policy Research Initiatives 6, 2003.

KAUFMAN, H. F. Toward an interactional conception of community. Social Forces, vol.38, n.1, p. 8-17, 1959.

KINKER, S. Ecoturismo e Conservação da Natureza em Parques Nacionais. São Paulo: Papirus, 2002.

KITAMURA, P.C. A Amazônia e o desenvolvimento sustentável. Brasília: EMBRAPA, 1994.

KOKA, B.R.; PRESCOTT, J.E. Strategic alliances as social capital: A multidimensional view. Strategic Management Journal, 23, p. 795-816, 2002.

LAI, P. H.; NEPAL, S. K.Local perspectives of ecotourism development in Tawushan Nature Reserve, Taiwan. Tourism Management, vol.27, n.6, p.1117-1129, 2006.

LAMNEK, S. Qualitative Sozialforschung. Bd. 2. 3. Aufl. Psychologie Verlags Union. Munchen, Weinheim, 1995. 
Ecotourism, social and human capitals, and identity valorization: the communities of Tapajós (PA), Brazil.

LEME, F. B. M.; NEVES, S. C. Planejamento, Turismo e Cultura: O Contato com o Outro como Fator de Sustentabilidade para Movimentos Identitários. In: ÁVILA, M. A. (Org.) Política e Planejamento em Cultura e Turismo. Ilhéus, BA: Editus, Editora da UESC, 2009, p.181208.

LESSA, R. Amazônia: As raízes da destruição. São Paulo: Atual Editora Ltda, 1991.

LIMA, I. B. de. Deforestation in Amazonia and local environmental governance. Tese de mestrado não publicada, School of International Relations, The University of Japan, YamatoMachi, 2002.

LIMA, I. B. de. The macro geopolitics of ecotourism: competing discourses and collaboration in New Zealand and Brazil. Tese de doutorado não publicada, The University of Waikato, Hamilton, NZ, 2008.

LINDBERG, K.; HAWKINS, D. E. Ecoturismo: Um Guia para Planejamento e Gestão. São Paulo: SENAC, 2001.

LOZANO, J., GOMEZ, C.; REY-MAQUIEIRA, J. An analysis of the evolution of tourism destinations from the point of view of the economic growth theory, FEEM Nota di Lavoro, 2006.

MELLO, de M. Ecoturismo no Ambiente do Cerrado e Movimentos Sociais. In: ALMEIDA, M. G. (Org.) Paradigmas do Turismo. Goiânia: Editora Alternativa, 2003, p. 51-60.

MITCHELL, C. (1998). Entrepreneurialism, commodification and creative destruction: A model of post-modern community development. Journal of Rural Studies, 14, p. 273-286, 1998.

MULDERA, K., ERICKSONB, J.; COSTANZA, R. The contribution of built, human, social and natural capital to quality of life in intentional and unintentional communities. Ecological Economics, vol. 11, 2005.

NEIMAN, Z.; MENDONÇA, R. Ecoturismo no Brasil. Barueri: Manole, 2004.

NEIMAN, Z.; RABINOVICI, A. (Orgs). O Turismo e o Meio Ambiente no Brasil. São Paulo: Manole, 2009.

PAGE, S.; DOWLING, R.K.D. Ecotourism. Themes in tourism. New York: Prentice Hall, 2001.

PANELLI, R. Rural health and wellbeing. In: Bock, B.B.; Shortall, S. (Eds.), Rural Gender Relations. Oxfordshire UK: CABI Publishing, p. 317-344, 2006.

PEARCE, D. G. Tourism development. London: Longman, 1989.

PERKINS, H. Commodification: re-resourcing rural areas. In: CLOKE, P.; MARSDEN, T.; MOONEY, P. (Orgs.), Handbook of Rural Studies. London: SAGE, 2006.

PINTO, L.F. Amazônia: no rastro do saque. São Paulo: HUCITEC, 1980.

PONCHIROLLI, O. O Capital humano como elemento estratégico na economia da sociedade do conhecimento sob a perspectiva da teoria do agir comunicativo. Florianópolis, Universidade Federal de Santa Catarina: Engenharia de Produção: 78, 2000.

PRETTY, J.; FRANK, B. R. Participation and social capital formation in natural resource management: achievements and lessons, procedimentos para Conferência Landcare 2000, 69 March, Melbourne, 2000. 
Lima, I.B de; d'Hauteserre, A.M.

PRETTY, J.; WARD, H. Social capital and the environment. World Development, vol. 29, p. 209-227, 2001.

PUTNAM, R. D. Bowling alone: America's declining social capital. Journal of Democracy, vol. 6, p. 65-78, 1995.

PUTNAM, R. D. Social capital: measurement and consequences. Canadian Journal of Policy Research, vol.2, n.2, p. 41-52, 2001.

PUTNAM, R. D. (Ed.). Democracies in Flux: The evolution of social capital in contemporary society. New York: Oxford University Press, 2002.

REDCLIFT, M. Sustainable Development (1987-2005): An Oxymoron Comes of Age. Sustainable Development, Vol. 13, No. 4, 2005, pp. 212-227.

ROCKTAESCHEL, B. M. M. Terceirização em Áreas Protegidas: Estímulo ao Ecoturismo no Brasil. São Paulo: Editora Senac, 2006.

RODRIGUES, A. B. (Org.) Ecoturismo no Brasil: Possibilidades e Limites. São Paulo: Ed. Contexto, 2003, 136p.

ROE, D.; PAGE, C. A.; MEYER, D. Tourism and the poor: Analysing and interpreting tourism statistics from a poverty perspective. PPT partnership working paper, 16, ODI, IIED and CRT, London, 2004.

RUSCHMANN, D. V. de M. Turismo e Planejamento Sustentável: A Proteção do Meio Ambiente. Campinas, SP: Papirus, 1997.

SARANTAKOS, S. Social research. Melbourne: Macmillan Education, 1993.

SCHALLER, D.T. (1996). Indigenous Ecotourism in the Ecuadorian Amazon: A case study. University of Minnesota, USA. Disponível em: http://www.geog.umn.edu. Acesso: 01/11/2007.

SCHEYVENS, R. Ecotourism and the empowerment of local communities. Tourism Management, vol. 20, n. 2, p. 245-249, 1999.

SCHEYVENS, R. Tourism for development: Empowering communities. New York: Prentice Hall, 2002.

SILVEIRA, I. Ecoturismo: etnodesenvolvimento e inclusão social no Amazonas. Revista de Turismo y Patrimônio Cultural, vol.3, n.1, p. 63-77, 2005.

SNUC - Sistema Nacional de Unidades de Conservação, Lei no 9.985, 18 de julho de 2000. Disponível em: < http://www.mma.gov.br/sitio/index.php? ido=conteudo.monta\&idEstrutura=240>. Acessado em: 28 of April, 2011.

SOBEL, J. Can we trust social capital? Journal of Economic Literature, v. 50, p.139-154, 2002.

SOUZA, A. M.; CORREA, M. V. M. Turismo: Conceitos, Definições e Siglas. Manaus: Editora Valer, 2000.

STEDMAN, R. C. Sense of place and forest science: Toward a program of quantitative research, Forest Science, vol. 49, p. 822-829, 2003.

STRONZA, A.; GORDILLO, J. Community views of ecotourism. Annals of Tourism Research, vol.35, n.2, p. 448-468, 2008. 
Ecotourism, social and human capitals, and identity valorization: the communities of Tapajós (PA), Brazil.

STROOMBERGEN, A., ROSE, D.; NANA, G. Review of the statistical measurement of human capital, Statistics New Zealand, p. 1-56, 2002.

TALBOT, L.; WALKER, R. Community perspectives on the impact of policy change on linking social capital in a rural community. Health and Place, vol.13, n.2, p. 482-492, 2007.

TOCANTINS, L. Amazônia: Natureza, homem e tempo. Rio de Janeiro: Editora Civilização Brasileira S.A, 1982.

WEARING, S.; NEIL, J. Ecotourism: Impacts, potential and possibilities. Oxford, UK: Butterworth Heinemann, 1999.

WEAVER, D. B. The encyclopedia of ecotourism. New York: CABI Publishing, 2001a.

WEAVER, D. B. Ecotourism. Melbourne: John Wiley \& Sons Australia, Ltd, 2001b.

WOESSMANN, L. Cross-country evidence on human capital and the level of economic development: The role of measurement issues in education. Historical Social Research, vol. 27, n. 4, p. 47-76, 2002.

WOOLCOCK, M. (1998). Social Capital and economic development: Toward a theoretical synthesis and policy framework. Theory and Society, vol. 27, n.2, p. 151-208.

YIN, R. K. Case study research: design and methods. California: Sage Publications, 1994.

Endnotes: The president of the Association of Maripá, Ascopram, Isaac as well as Maria Isolina, Raimundo, Raimundinho, Manduca, e Beto. The Ibama's staff and the coordinator of the Tapajós/Arapiuns-Tapajoara Associations Organization, Cleida Santos, also contributed significantly with the research by providing updated information in November 2010.

Acknowledgments: The fieldwork in Amazônia was part of a doctoral study fully sponsored by the New Zealand Agency for International Development (NZAID), managed by the Ministry of Foreign Affairs and Trade (MFAT). The authors also thank the support and attention given by the New Zealand Embassy's staff in Brasilia, in particular to Mrs. Heloísia Fontes, policy support officer.

Ismar Borges de Lima: Universidade Federal de Goiás

Email: ismarlima@yahoo.com.br

Link para o currículo Lattes: http://lattes.cnpq.br/1226725450970361

Anne-Marie d'Hauteserre: University of Waikato, New Zealand

Email: adhautes@waikato.ac.nz

Link para o currículo: http://www.waikato.ac.nz/wfass/staff/gtep/adhautes

Data de submissão: 19 de janeiro de 2011.

Data do aceite: 30 de abril de 2011 . 